\title{
Conceptualising Intangible Heritage in Urban Environments: Challenges for Implementing the HUL Recommendation ${ }^{1}$
}

\author{
Harriet Jane Deacon \\ Centre for Dance Research, Coventry University, Coventry, United Kingdom \\ Email: harriet@conjunction.me.uk
}

\begin{abstract}
The Historic Urban Landscape (HUL) Recommendation (UNESCO 2011) suggests that heritage management should be holistic, integrated, people-centred and focused on sustainable development goals. Both tangible and intangible heritage should be taken into account, allowing for appropriate change over time. A variety of stakeholders should be involved in planning processes, including all levels of government, NGOs and communities. Intercultural dialogue and mediation, as well as tools such as documentation, inventorying and mapping should be used to identify multiple layers of heritage. Implementing the Recommendation thus offers a wonderful opportunity to develop consultative, bottom-up, integrated planning for sustainable development in urban areas. This paper suggests that one barrier to integrating management planning for tangible and intangible heritage is a persistent confusion about what 'intangible heritage' is and why it deserves protection. Is it the values that local communities associate with their environment ('intangible values'), or is it cultural practices that they happen to perform in that environment (intangible cultural heritage, or ICH)? Should 'intangible heritage' be managed as an attribute attesting to the authenticity of tangible fabric, or as a subject of safeguarding in its own right? If it means all these things at the same time, why is the same concept being used for so many different ideas and what are the consequences? The paper will suggest that a clearer conceptual understanding of intangible heritage is necessary to effectively integrate it into urban management strategies under the HUL approach.
\end{abstract}

KEYWORDS intangible heritage, Historic Urban Landscape, UNESCO intangible heritage convention

Received September 15, 2018; accepted December 18, 2018.

\section{Introduction}

In his insightful chapter in Reconnecting the City, Jigyasu $(2015,129)$ argues that in urban planning, intangible heritage is usually not well documented, and 'not properly taken into account'. He explains, 'There is a lack of understanding of the complexity and pervasiveness of intangible values, and of their direct relationship with the physical structure of the city.' Jigyasu suggests that part of the reason for this neglect lies in the fact that 'master planning with rigid land use zoning' focusing on tangible fabric has dominated urban planning. He argues for a more 'holistic territorial approach that seeks to recognise multiple relationships that tie residents to their environment both in materialistic as well as non-materialistic terms' (2015, 143). He suggests that the approach taken in the Historic Urban Landscape (HUL) Recommendation (UNESCO 2011) can 'give intangible heritage values their rightful importance in the process of interpretation, planning and conservation of historic cities' $(2015,130)$.

The HUL Recommendation emerged out of efforts to address the management of urban World Heritage properties facing increasing threats from rapid urbanisation, growing tourism pressure, a concentration of urban regeneration and development projects in historic inner cities (Van Oers 2010). The $29^{\text {th }}$ World Heritage Committee in 2005 recommended 'that the General Conference of UNESCO adopt a new Recommendation ... on the subject of conservation of historic urban landscapes, with special reference to the need to link contemporary architecture to the urban historic context' (Decision 29 COM 5D, Van Oers 2010, 8). On November 10 2011, UNESCO's General Conference adopted the HUL Recommendation on the Historic Urban Landscape by acclamation. UNESCO now coordinates advice on the implementation 
of the Recommendation through an initiative located within the World Heritage Centre (UNESCO 2018).

The HUL Recommendation is based on the principle that heritage management should be holistic, integrated, people-centred and focused on sustainable development goals. Aligned with the 'cultural landscapes' model, and following the definition in the 2005 Vienna Memorandum (UNESCO 2005; Van Oers 2010), the 'historic urban landscape' is defined very broadly in the Recommendation. It is defined as the urban area which is 'the result of an historic layering of cultural and natural values and attributes, extending beyond the notion of "historic centre" or "ensemble" to include the broader urban context and its geographical setting.' This contrasts with earlier models that focused on protecting historic centres from development (for example, the Nairobi Recommendation [UNESCO 1976]). The HUL approach 'confirms a progressive enlargement of the concept of landscape, not only in a quantitative sense (the territorial dimension in which the conservation action is included) but also in a qualitative sense, due to the range of elements (belonging to both material and immaterial heritage)' (Angrisano et al. 2016, 166-167).

The HUL Recommendation reflects a communityfocused approach to heritage management based on the active involvement of a variety of stakeholders in planning processes, including all levels of government, NGOs and communities, using intercultural dialogue and mediation, as well as tools such as documentation, inventorying and mapping. Heritage management is positioned as an integral part of the development of cities, rather than as a barrier to such development. This was reaffirmed in the New Urban Agenda (United Nations 2016), adopted at the United Nations Conference on Housing and Sustainable Urban Development (Habitat III) in Ecuador on October 20 2016, and endorsed by the United Nations General Assembly on December 23 2016. The NUA, and the 2030 Agenda for Sustainable Development and Sustainable Development Goals (United Nations 2015) support the idea that 'cultural heritage and landscape conservation/regeneration effectively contribute to making cities and human settlements safe, inclusive, resilient and sustainable' (Angrisano et al. 2016, 166).

Implementing the HUL approach thus potentially offers a wonderful opportunity to develop consultative, bottomup, integrated planning for sustainable development in urban areas, that can address Jigyasu's concerns about the inadequate attention paid to intangible heritage in urban planning. In this paper, we suggest, however, that paying more attention to intangible heritage will not improve urban planning if we do not clearly define what we mean by the concept. Of course, tangible and intangible heritage are intertwined, and all heritage is intangible because it is socially constructed (Smith 2006). For the purposes of management, however, lumping everything together is not effective: planners need to differentiate between fabric, cultural practices and heritage significance (or values) in order to identify and sustain heritage value.

Thus, in order to address the tangible and intangible dimensions of urban heritage effectively within a single management framework, it is necessary to have a clearer concept of the intangible. To this end, we suggest that it is important to distinguish the concept of 'intangible values' from intangible cultural heritage $(\mathrm{ICH})$ practices. 'Intangible values' are the meanings or socio-cultural significances associated with (urban) environments, usually by local communities, i.e. WHY the place or activities in the place are important to them. ICH is cultural practice, i.e. WHAT activities people do that they consider to be heritage. Reducing slippage and confusion between these concepts of the intangible (or 'conceptual inflation' of the term) can help develop a better balance between tangible conservation and intangible safeguarding measures within integrated management frameworks based on the HUL Recommendation.

To demonstrate this point, the paper will first explore how intangible heritage has historically been conceptualised under two different Conventions at UNESCO, before discussing the implications for designing and implementing integrated approaches to heritage management in urban areas under the HUL Recommendation.

\section{Conceptualising Intangible Heritage}

The World Heritage Convention, adopted in 1972, aimed at the conservation of 'tangible' heritage properties, or places with Outstanding Universal Value (UNESCO 1972). At around the same time that this Convention was approved, the Bolivian government requested UNESCO to start considering protection of folklore. A few decades of debate, experiment and consultation, culminating in the UNESCO Convention for the Safeguarding of the Intangible Cultural Heritage (UNESCO 2003), the first UNESCO Convention to address the safeguarding of heritage practices and expressions such as music or traditional medicine. Both conventions had their origins in concerns about the destruction or disappearance of heritage, and aim to promote its enduring value to humanity. The Intangible Heritage Convention was modelled in many ways on the World Heritage Convention, offering mechanisms 
for awareness-raising such as national inventories and international heritage lists (the Representative List and the Urgent Safeguarding List) and following some of the administrative mechanisms and textual formulations of the older Convention (Smeets and Deacon 2017).

However, the two Conventions not only define the object of heritage protection rather differently, as tangible or intangible heritage, they also take a somewhat different approach to heritage identification and management. These differences in the conceptualisation of the intangible within the framework of UNESCO have a history and a politics that has been discussed extensively elsewhere (Smith 2006; Labadi 2013; Deacon and Smeets 2013) and will not be covered here in depth. Also, similar concepts are used outside the framework of these Conventions, and outside UNESCO, but that is the subject of another paper. In this paper, the texts of the World Heritage and Intangible Heritage Conventions describe 'intangible heritage' will be used to provide some illustrations of the different approaches to conceptualisation of the intangible that are relevant to its interpretation within the HUL framework.

\section{Intangible Values and the World Heritage Convention}

Under the World Heritage Convention and its Operational Guidelines, intangible heritage, while not formally defined, is mentioned as an attribute attesting to the authenticity of World Heritage properties, i.e. 'intangible values'. Establishing outstanding universal value involves establishing the authenticity and integrity of the property (UNESCO 2017). Stovel (2007) defines 'authenticity' as the ability of aspects of a (World Heritage) property to convey its value (i.e. Outstanding Universal Value), while 'integrity' is the ability of the property (as defined and then managed) to secure and sustain this value. Authenticity refers to the credibility of the evidence presented, and integrity to the appropriateness of the size, condition and scope of the property to support claims of value (Deacon and Smeets 2013). The authenticity of World Heritage properties may be attested by the presence of attributes such as 'traditions, techniques and management systems', 'language and other forms of intangible heritage' and 'spirit and feeling' (UNESCO 2017, para 82).

The notion that 'spirit and feeling' might be an attribute affecting the authenticity of places has its origins in para 13 of the Nara Document of 1994 (UNESCO 2017, Annex 4):

Depending on the nature of the cultural heritage, its cultural context, and its evolution through time, authenticity judgments may be linked to the worth of a great variety of sources of information. Aspects of the sources [used to determine authenticity] may include form and design, materials and substance, use and function, traditions and techniques, location and setting, and spirit and feeling, and other internal and external factors.

The Nara Document was an attempt to expand the Venice Charter 'test of authenticity, based on design, material, workmanship and setting, considered with reference to the tangible material of the heritage (Jokilehto 2006) to allow for change over time, and socio-cultural context. It took some time (11 years, in fact) for the ideas in the Nara Document to be included in the Operational Guidelines. Expressing this discomfort, paragraph 83 notes that 'Attributes such as spirit and feeling do not lend themselves easily to practical applications of the conditions of authenticity, but nevertheless are important indicators of character and sense of place, for example, in communities maintaining tradition and cultural continuity'.

'Spirit and feeling', taken from the Nara Document, thus cover the meanings associated with places by local communities. These local meanings help to establish the social significance of a place which may influence conservation actions in values-based cultural heritage management approaches (e.g., Australia ICOMOS 1999, Clark 2001). By contrast, the Operational Guidelines text 'management systems ..., language and other forms of intangible heritage' was included after the Great Zimbabwe meeting on authenticity and integrity in the African context, held in May 2000 (UNESCO 2017, Annex 4). The latter idea, linked to 'traditions' and 'techniques', comes closest to the definition of ICH in the Intangible Heritage Convention because it focuses on cultural practice and expression.

Discourse about intangible heritage within ICOMOS (the International Council on Monuments and Sites), a global non-government organisation that provides advice to the World Heritage Committee on cultural heritage properties, exhibits a similar approach to conceptualising intangible heritage. The ICOMOS Xi'an Declaration of 2005 refers to the importance of 'diversified sources of information' (including local meanings) as well as 'traditional knowledge and other intangible forms and expressions' in the 'conservation of context' for World Heritage properties (ICOMOS 2005). The ICOMOS Québec Declaration of 2008 on 'the preservation of the spirit of place ... through the safeguarding of tangible and intangible heritage' suggests that intangible heritage can include both 'values', 'memories' and 'written documents' (i.e. 
stories about why a place is important) as well as 'festivals', 'rituals' and 'traditional knowledge' (i.e. cultural practices associated with a place). For this reason, the strongest aspect of the Québec Declaration is not perhaps its contribution to a 'new conceptual vocabulary' for heritage management that includes intangible heritage, but its recognition of the diversity of meanings communities associate with places (ICOMOS 2008).

In ICOMOS, intangible heritage can thus mean cultural practice, 'intangible values' or, in some cases, 'spirit of place' itself-the intangible significance informed by both tangible and intangible values. This lack of clarity may be one of the reasons why ICOMOS has not yet been able to draft a declaration specifically on intangible heritage management. Efforts were made between about 2007 and 2011 to develop a 'Teemaneng Declaration' on this topic, after an International Scientific Committee on ICH was established in 2006, but there has been little progress. ICOMOS has been accredited as an NGO under the Intangible Heritage Convention but initially showed relatively little interest in participating in the activities of that Convention. Failing to submit its first report to the Intergovernmental Committee of the Intangible Heritage Convention resulted in de-accreditation between 2015 and 2017, for example. The tentative position of ICOMOS vis a $v i s$ the Intangible Heritage Convention reveals its discomfort with the concept of ICH, as opposed to 'spirit of place'.

\section{Conceptualising Intangible Heritage under the Intangible Heritage Convention}

The Intangible Heritage Convention defines a very wide range of cultural practices and skills as ICH in article 2.1 (UNESCO 2003):

The 'intangible cultural heritage' means the practices, representations, expressions, knowledge, skills-as well as the instruments, objects, artefacts and cultural spaces associated therewith-that communities, groups and, in some cases, individuals recognise as part of their cultural heritage. This intangible cultural heritage, transmitted from generation to generation, is constantly recreated by communities and groups in response to their environment, their interaction with nature and their history, and provides them with a sense of identity and continuity, thus promoting respect for cultural diversity and human creativity.

In an attempt to make this rather vague and all-encompassing concept clearer, article 2.2 lists several exemplary domains of ICH: '(a) oral traditions and expressions, including language as a vehicle of the intangible cultural heritage; (b) performing arts; (c) social practices, rituals and festive events; (d) knowledge and practices concerning nature and the universe; (e) traditional craftsmanship.'

The Convention thus acknowledges the wide range of cultural expressions that communities, groups and individuals concerned could identify as their 'intangible heritage. The key point here is that the Convention places the focus on cultural practices rather than ideas or values. The Operational Directives (UNESCO 2018) do refer to the functions, meanings and values communities associate with intangible heritage elements, but they are not described as 'intangible values', or treated as equivalent to 'intangible heritage' elements.

Although 'oral traditions' and 'knowledge' are mentioned in the domains of article 2.2, and they could be considered ideas associated with places, under the Intangible Heritage Convention they would not primarily be considered 'memories' or 'oral histories' that express the 'intangible values' of those places. They would be considered intangible heritage practices worthy of safeguarding in their own right. The definition in article 2.1 also mentions associated 'cultural spaces' and objects. Other articles in the Convention refer to 'forums and spaces' and 'natural spaces and places of memory' that are needed for the performance or expression of ICH (UNESCO 2003, articles 13-14). However, 'cultural spaces' are indicated in these texts primarily because they are the context in which ICH practices and expressions happen: they are not the focus of safeguarding, and they are not included in the exemplary domains of ICH. For intangible heritage to be considered under the Convention, it does not need to be part of historic sites with locally, nationally or internationally recognised heritage status.

Thus, although its definition of intangible heritage is very broad, the Intangible Heritage Convention focuses on helping communities safeguard their intangible heritage as cultural practice in its own right. 'Intangible heritage' as practice (i.e. WHAT is done) is distinct from the meaning and value (significance) of a practice (i.e. WHY it is done). The meaning and value of $\mathrm{ICH}$ is considered important under the Convention, but it is not the same as the ICH itself $^{2}$. By contrast, in the case of World Heritage, intangible heritage is primarily conceived as an attribute of the heritage property that speaks to its outstanding universal value.

\section{Intangible Heritage and the HUL Recommendation}

Compared to the World Heritage Convention, intangible heritage is more strongly prioritised, but no more clearly 
defined, in urban planning approaches such as the HUL. Intangible heritage is foregrounded in the HUL approach because of its association with community consultation (Blake 2008). Yet the HUL Recommendation does not define the term intangible heritage, which allows for conceptual slippage between ideas of cultural practice and the 'intangible' values of a place. This can limit the extent to which ICH management is included in management plans.

The Vienna Memorandum, which prefigured the HUL Recommendation, referred to 'the emotional connection between human beings and their environment, their sense of place' (UNESCO 2005, para 15) and the 'socio-cultural' values associated with place (UNESCO 2005, para 7). It did not mention 'intangible heritage' as such. By contrast, the HUL Recommendation explicitly refers to the 'tangible and intangible components' of urban heritage (UNESCO 2011, para 3). It places 'social and cultural practices and values ... and the intangible dimensions of heritage as related to diversity and identity' within the 'broader urban context' of the 'historic centre' or 'ensemble' (UNESCO 2011, para 9). It states that 'Knowledge and planning tools should help protect the integrity and authenticity of the attributes of urban heritage. They should also allow for the recognition of cultural significance and diversity, and provide for the monitoring and management of change to improve the quality of life and of urban space.' (UNESCO 2011, para 24(b)) The Recommendation states that regulatory systems 'may include legislative and regulatory measures aimed at the conservation and management of the tangible and intangible attributes of the urban heritage, including their social, environmental and cultural values' (UNESCO 2011, para 24(c)).

The HUL Recommendation thus encourages integrated tangible and intangible heritage management. However, the conceptual slippage between ICH as practice and the 'intangible' values of places could mean that in implementing the Recommendation, greater emphasis is placed on values and memories associated with (urban) places, often perceived as assets that do not require heritage risk assessment or management interventions. Planning should encompass intangible heritage practices and identify where they need support to continue in an (urban) place, whether or not they align with the 'spirit' of that place as defined by its built environment.

To take one example, the Ballarat (Australia) HUL planning framework, presented as a case study in The HUL Guidebook, showcases strong 'community-based approaches' to HUL implementation (WHITRAP 2016,
46). Community-led management of ICH safeguarding is particularly evident in regard to what the plan terms the 'Aboriginal cultural heritage' of the Wadawurrung and the Dja Dja Wurrung peoples of the area. However, in the plan as a whole, the focus remains on identifying 'intangible values' associated with places as opposed to identifying and managing ICH practices. For example, funding has been allocated specifically to 'telling the stories of Ballarat's heritage places' (City of Ballarat 2017, 33), and supporting traditional trades 'needed for conserving heritage places and traditional knowledge' (City of Ballarat 2017, 39). There is less emphasis on identifying and fostering endangered forms of storytelling and craft unrelated to the built fabric.

The Ballarat plan does recognise the importance of music traditions among diverse communities, including Aboriginal and Chinese, in the city. But even here, the focus remains on locating spaces for events, and on 'intangible values' identified through historical reflections. For example, the 'SongWays Music Mapping' visualisation tool geo-locates pictures of places where music is performed, such as churches or theatres (City of Ballarat 2018a). The SongWays Stories website presents a Live Music Roster from 1956-2002, and historical memories of music in the city (City of Ballarat 2018b). The planning framework does not seem to map, identify and foster networks of music teachers associated with specific traditions in the city, or suppliers of heritage song texts or traditional instruments. Perhaps more ICH-specific activities will be part of the plan in future. In the meantime, the Ballarat Heritage Database maintained by the city authorities remains a database of places (City of Ballarat 2018c). and does not include the crafts, food traditions, festivals or other forms of ICH in the city. 'Heritage' grants and loans are available for heritage properties alone (City of Ballarat 2018d). Funding for ICH seems to be included in general arts funding.

Thus, even in this otherwise excellent plan, intangible heritage is primarily envisaged in terms of 'intangible values' that inform the interpretation of the place, such as stories and memories. Support for ICH as practice is focused mainly on showcasing existing cultural practice or providing spaces for it, rather than also mapping or inventorying it and its vulnerabilities. Interventions for $\mathrm{ICH}$ safeguarding, such as making investments in maintaining practice and transmission, are thus not easily integrated in the planning process. The claim that the plan covers both tangible and intangible heritage management is enabled by the slippage between the two concepts of intangibility. 


\section{The Importance of Distinctions}

Why is it important to distinguish between 'intangible values' and ICH in heritage management frameworks such as the HUL?

It is of course difficult to separate 'intangible values' and ICH when the 'practices' that could be identified as intangible heritage are linked to knowledge, beliefs and skills. How and why should we separate what people do from why they do it? Conflation of the various concepts of the 'intangible' aligns with theories about the close relationship between tangible and intangible heritage, and between ideas, environments and objects or buildings (e.g., ICOMOS 2008, and the cultural landscape approach). Many communities do not distinguish between tangible and intangible heritage (Munjeri 2008). What, then, is the problem with expanding the idea of intangible heritage to include both values and practices? Are they not intertwined? In picking apart the notion of intangible heritage, are we not tampering unnecessarily with the soul of the city?

The idea that 'intangible heritage values' and 'intangible heritage practices' or ICH are the same thing may arise partly from their common function as attributes attesting to the authenticity of World Heritage properties. Even beyond World Heritage management, as the views of local communities, both these concepts are often collectively represented as 'the people's voice' in heritage planning. As Jigyasu puts it, intangible heritage, 'preserved by local communities in the form of their knowledge and skills and also through rituals, festivals and other social activities' is the 'soul' and tangible heritage is the 'body' of the historic urban landscape (Jigyasu 2015, 130). He shows how 'collective memories' and 'sacred geometries', as well as festivals or rituals in urban areas affect (and are affected by) urban design, boundaries and routes in Indian cities.

There are three main reasons why conceptual confusion and inflation of intangible heritage is problematic for the implementation of integrated management planning.

First, the idea of 'intangible values' is tautologous because all values are a human intellectual construct, and thus are by their very nature abstract, immaterial or 'intangible. The term 'significance' or 'value' is sufficient. If 'intangible values' are simply equivalent to 'socio-cultural significance' in urban planning, then this may merely encourage community consultation, and not the documentation of intangible heritage practices, such as performance, music, rituals and festivals, or their safeguarding under the HUL framework. Intangible heritage could for example be represented in a management plan almost entirely through statements about community values of the site.
This represents a missed opportunity for truly integrated heritage management planning.

Second, the idea that everything is linked, or that all heritage is intangible (Smith 2006), is not particularly useful in management planning, where an effort is made to disentangle the elements making up a complex context and map their relationships. One interesting feature of 'intangible heritage' as practice is that it is not at all intangible. It involves people acting on their environment, performing with their bodies, making sounds and objects, and thereby physically altering their context. The word 'intangible' or 'immaterial' to describe heritage practices is a political term, to differentiate the Intangible Heritage Convention from the World Heritage Convention; it is not a methodologically useful term for management planning.

The conflation of the 'intangible' significance associated with (tangible) heritage, and the intangible heritage (practice) that might carry that significance thus makes decision-making for management planning more difficult. In tangible heritage management frameworks such as the Burra Charter, a distinction is made between heritage significance or value and 'tangible' fabric. Managing the significance rather than the fabric of heritage sites helps to make decisions accommodating multiple perspectives, conservation priorities and change over time. The Intangible Heritage Convention texts make a similar distinction between the meaning or value of intangible heritage practices, and the practices themselves. This distinction could assist in managing complex urban environments where the safeguarding needs of intangible heritage elements need to be considered for their own sake. Aspects of both tangible or intangible heritage practices may be conserved symbolically by locals (i.e. the significance is retained), for example, even where the original fabric or practice is irretrievably lost or changed.

Finally, focusing on intangible heritage primarily as an attribute attesting to the authenticity of tangible fabric potentially fails to consider the safeguarding needs of intangible heritage elements 'on their own merit', which may be important to local communities. Such practices may in some cases be unrelated to, or in opposition to conservation of, tangible aspects of urban heritage (Jigyasu 2015, 138).

Thus, using the same concept for the significance of historic urban landscapes, and for an aspect of heritage elements that should be managed in those contexts, is tautologous, analytically weak and unsustainable if we are serious about integrating tangible and intangible heritage management, and listening to local communities in all their diversity. Understanding the values (significance) 

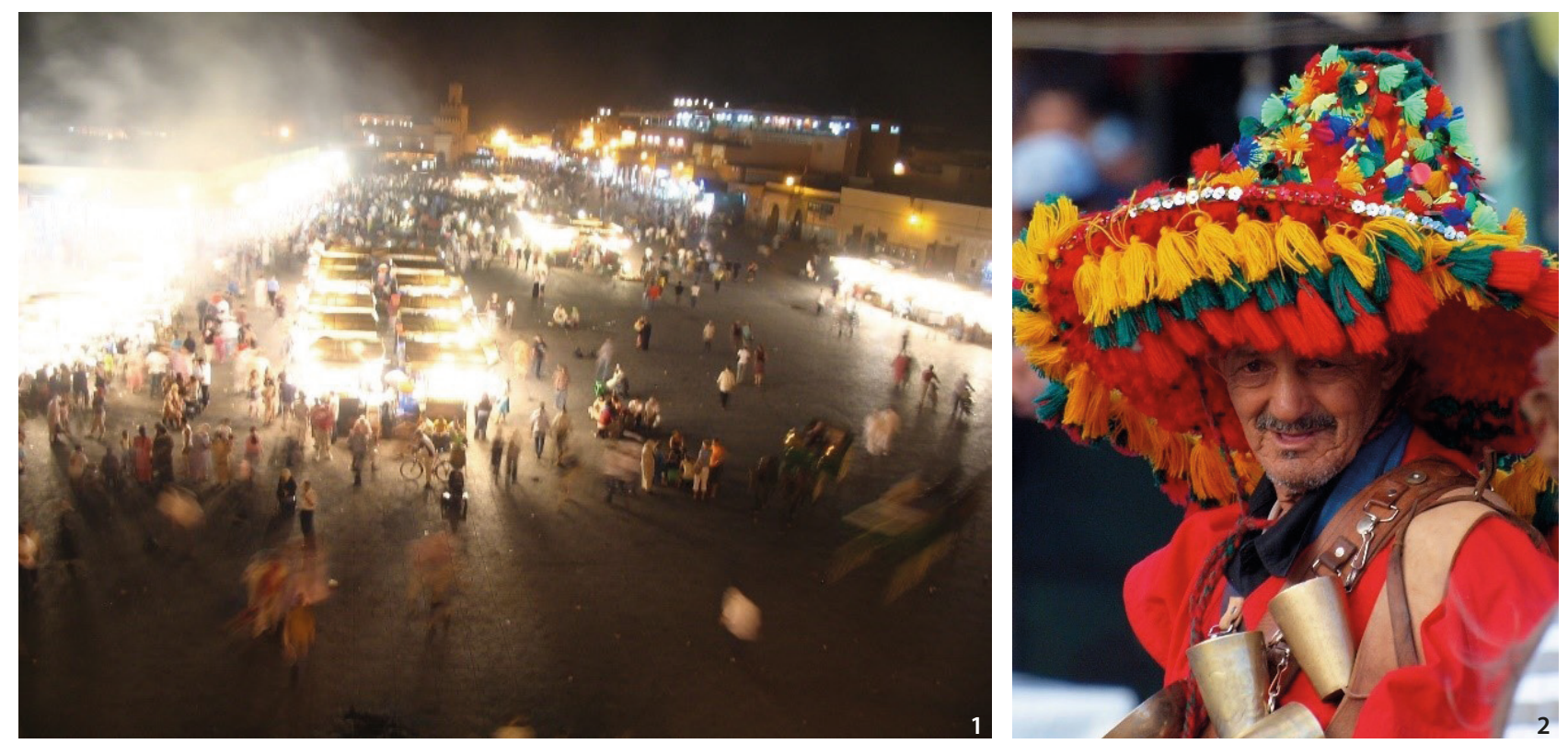

Figure 1 Main Square night market in Marrakech, Morocco (Source: Benjamin Vander Steen).

Figure 2 A local man sells drinking water at the Jemaa el-Fna Square in Marrakech, Morocco (Source: Torrenegra).

associated with places (as well as practices) helps to direct and prioritise management action across the multiplicity of layered values in the urban context. Understanding the nature of the cultural heritage practices themselves (or indeed the urban fabric) within an urban area helps to identify specific management actions to safeguard those practices or associated places.

Paying attention to how we are conceptualising heritage in management plans is particularly important as the historical focus on managing heritage fabric, for example under the World Heritage Convention, has not been matched, in most countries, by an equal expenditure of time and resources to safeguard $\mathrm{ICH}$, for example under the Intangible Heritage Convention.

\section{Developing Integrated Planning Approaches in Jemaa el-Fna Square in Marrakech, Morocco: The Need for a HUL Approach}

The case of Jemaa el-Fna Square in Marrakech, Morocco, illustrates the importance of integrated planning approaches such as the HUL in creating bridges between management of tangible and intangible heritage, including both the fabric and values associated with the built environment and the ICH practices in the urban area (Figure 1).

Jemaa el-Fna is a market place in Marrakech's historic Medina quarter. The Medina as a whole was inscribed on the UNESCO World Heritage List in 1985. The focus of the World Heritage inscription was mainly on the ramparts, the Koutoubia Mosque, the kasbah, the Saâdians tombs, the ruins of Badiâ Palace, Menara water feature and pavilion, although it included the trading sites or souks, such as Jemaa el-Fna. When the Retrospective Statement of Outstanding Universal Value (SOUV) was adopted for the 'Medina of Marrakesh' as a World Heritage property in 2010, it cited criterion (i) for the Medina's masterpieces of architecture and art, criterion (ii) for its historical role in medieval urban development, criterion (iv) because it is an example of a 'major Islamic capital of the western Mediterranean', and criterion ( $\mathrm{v}$ ) because it is an 'outstanding example of a living historic town with its tangle of lanes, its houses, souks, fondouks, artisanal activities and traditional trades' (UNESCO 2010, 19).

Although the words 'intangible heritage' are not specifically mentioned in the SOUV for the Medina, the OUV of the Medina as 'a living historic town' is supported by its 'spirit of place' as a trading hub for local people; the continued use of traditional trades and artisans in restoration of the buildings support the authenticity of the property (UNESCO 2010, 20). The Medina's 'intangible heritage, in the World Heritage approach, is thus not primarily the activity of trading-such as the trading practices and performances of the Jemaa el-Fna Squarebut the meaning of trading which informs the 'living historic town'. It also includes activities that maintain the buildings as authentic traditional fabric. Interventions in, and management of, the Medina as a World Heritage property have thus focused on the built heritage. The 
SOUV stated that the integrity of the property was primarily threatened by factors that affected the buildings: 'pressure from urban development, uncontrolled alterations to ... houses, the abandonment of the Khettaras (underground drainage galleries) and exploitation of the palm groves' (UNESCO 2010, 20). No mention was made in the SOUV of interventions to ensure the continuity of the cultural practices that sustained its 'spirit of place' as a trading hub (Figure 2).

In 2001, the 'Cultural space of Jemaa el-Fna Square' was proclaimed one of the Masterpieces of Oral and Intangible Heritage of Humanity in an early UNESCO programme to recognise intangible heritage. In 2008, it was inscribed on the Representative List of the Intangible Cultural Heritage of Humanity under the 2003 Convention. The focus of the 'Cultural space of Jemaa el-Fna Square' $\mathrm{ICH}$ inscription was on the activities conducted in the square by preachers, storytellers, poets, snake charmers, Berber musicians and other performers, and the sale of traditional medicine, drinking water, local foods, henna tattooing and so on. But because the inscription built on the earlier Masterpieces proclamations which did not require safeguarding plans, there were no formal management interventions proposed in the ICH nomination file (a serious weakness in the system), nor were major such interventions implemented.

In their first Periodic Report to the Intergovernmental Committee (Morocco 2014), Morocco noted that while the inscription had raised 'awareness of the cultural and historic importance of the space (for locals and overseas visitors) and stimulated the practitioners to continue to enact their intangible cultural heritage in place', 'the number of storytellers has continued to decline' and they had concerns about 'folklorisation' and 'the expansion of commercial activities' in the Square. Commercial businesses were for example squeezing out traditional traders and performers in the square, especially storytellers, and young people were not encouraged to continue the traditions (see Tebbaa 2010). Such problems have not been resolved in later years (Beardslee 2016).

The dearth of actions implemented for ICH safeguarding in the 'Cultural Space of Jemaa el-Fna Square' is exacerbated by the focus of financial and planning attention on the built fabric of the 'Medina of Marrakesh' World Heritage property, and the idea that trading centres like this will retain 'intangible values' without management actions. In Marrakech, as elsewhere, an integrated management plan under the HUL framework could integrate a focus on historic urban landscape values - the value of the 'historic living town' as a trading hub-and on maintaining on the local community's trading and performance practices, alongside maintenance of the built fabric.

\section{Conclusion}

Under the World Heritage Convention, the idea of intangible heritage is primarily represented as intangible values' that give meaning to places, providing evidence of authenticity in statements of 'outstanding universal value' for World Heritage properties. Intangible heritage becomes worthy of attention primarily through its association with place. This conceptualisation of 'intangible values' has influenced heritage planning more generally, especially because of its associated with communitycentred planning approaches. However, the concept of 'intangible values' differs from the definition of intangible heritage used by the Intangible Heritage Convention, which focuses on safeguarding ICH, or cultural practices and expressions. Some ICH may be linked to specific places, but other practices may not. The fact that two very different conceptualisations of intangible heritage are being used is sometimes overlooked.

This paper suggests that although the HUL approach offers a very real advantage in managing heritage in urban areas, because of this conceptual confusion and indeed inflation of the concept of intangible heritage, it does not yet represent a significant advance towards the integrated management of tangible and intangible heritage, without the necessary clarifications. A lack of attention to intangible heritage as practice can mean that the implementation of the HUL Recommendation does not go much beyond a focus on conserving the authenticity and integrity of the built environment with some community flavour. A truly integrated approach would focus both on managing historic urban landscape values and on the local community or communities and the safeguarding of their practices. Safeguarding of intangible heritage practices might be included in management planning where they are located in specific places in the city or are more diffuse, and whether they attest to the authenticity of this built fabric, or not. Resources would be committed to the safeguarding of cultural practice.

A better understanding of the concept of 'intangible heritage' and how it is used in different UNESCO instruments can facilitate discussion within UNESCO, and between experts working on the World Heritage and Intangible Heritage Conventions. Often, people may be unaware that they are using the same term to talk about different 
subject matter. More importantly, when developing integrated heritage management tools beyond the HUL or UNESCO frameworks, a clearer conceptual framework can help us to recognise the assumptions structuring our approaches to identifying what constitutes our heritage, and what strategies represent truly integrated approaches to managing it in all its complexity. The HUL Recommendation could be a tool for helping to realise such an integration.

\section{Notes}

1. Thanks to Rieks Smeets and the anonymous reviewers of this journal for their inputs and comments on this paper.

2. As an aside, neither cultural practice nor the value ascribed to it are formally used to judge the authenticity of intangible heritage under the Convention. The Convention deliberately avoids mention of the terms 'authenticity' or 'integrity' in the traditional Venice Charter sense to enable community-defined judgements of authenticity. This is quite compatible with a community-centred reading of authenticity in the Nara Document (Deacon and Smeets 2013).

\section{References}

Angrisano, Mariarosaria, Paolo Franco Biancamano, Martina Bosone, Paola Carone, Gaia Daldanise, Fortuna De Rosa, Alfredo Franciosa et al. 2016. “Towards operationalizing UNESCO Recommendations on 'Historic Urban Landscape': A Position Paper.' Aestimum 69: 165-210.

Australia ICOMOS. 1999. The Burra Charter: The Australia ICOMOS Charter for Places of Cultural Significance. Burwood: Deakin University.

Beardslee, Thomas. 2016. "Whom Does Heritage Empower, and Whom Does It Silence? Intangible Cultural Heritage at the Jemaa el Fnaa, Marrakech.” International Journal of Heritage Studies 22 (2): 89-101.

Blake, Janet. 2008. “UNESCO's 2003 Convention on Intangible Cultural Heritage: The Implications of Community Involvement in 'Safeguarding." In Intangible Heritage edited by Smith, Laurajane and Natsuko Akagawa, 59-87. London: Routledge.

City of Ballarat. 2017. Our People, Culture and Place: A Plan to Sustain Ballarat's Heritage 2017-2030. Ballarat: City of Ballarat.

City of Ballarat. 2018a. "Ballarat SongWays Music Mapping." Accessed December 20 2018. http://www. hulballarat.org.au/songways.php

City of Ballarat. 2018b. "SongWays Stories." Accessed December 20 2018. http://www.hulballarat.org.au/cb_ pages/songways_stories.php

City of Ballarat. 2018c. "Ballarat Heritage Database." Accessed December 20 2018. http://www.ballarat.vic.gov. $\mathrm{au} / \mathrm{sh} /$ heritage/ballarat-heritage-database.aspx

City of Ballarat. 2018d. "Heritage Grants and Loans." Accessed December 20 2018. http://www.ballarat.vic.gov. $\mathrm{au} / \mathrm{sh} /$ heritage/heritage-grants-and-loans.aspx

Clark, Kate. 2001. Informed Conservation: Understanding Historic Buildings and Their Landscapes for Conservation. London: English Heritage.

Deacon, Harriet, and Smeets, Rieks. 2013. "Authenticity, Value and Community Involvement in Heritage Management under the World Heritage and Intangible Heritage Conventions." Heritage and Society 6 (2): $1-15$.

ICOMOS 2005. "Xi'an Declaration on the Conservation of the Setting of Heritage Structures, Sites and Areas." Accessed 20 December 2018. http://www.icomos.org/ charters/xian-declaration.pdf

ICOMOS 2008. "Québec Declaration on the Preservation of the Spirit of Place." Accessed 20 December 2018. https://www.icomos.org/quebec2008/quebec_declaration/pdf/GA16_Quebec_Declaration_Final_EN.pdf

Jigyasu, Rohit. 2015. “The Intangible Dimension of Urban Heritage." In Reconnecting the City: The Historic Urban Landscape Approach and the Future of Urban Heritage, edited by Bandarin, Francesco and Ron van Oers, 129-144. Chichester: Wiley-Blackwell.

Jokilehto, Jukka. 2006. "Considerations on Authenticity and Integrity in World Heritage Context." City \& Time 2 (1):1-14.

Labadi, Sophia. 2013. UNESCO, Cultural Heritage, and Outstanding Universal Value: Value-Based Analyses of the World Heritage and Intangible Cultural Heritage Conventions. Lanham: Rowman \& Littlefield.

Morocco. 2014. "Report on the Implementation of the Convention and on the Status of Elements Inscribed on the Representative List of the Intangible Cultural Heritage of Humanity." Submitted to Intergovernmental Committee for the Safeguarding of the Intangible Cultural Heritage, 9th session, UNESCO Headquarters, 24-28 November 2014.

Munjeri, Dawson. 2008. "Following the Length and Breadth of the Roots: Some Dimensions of Intangible Heritage." In Intangible Heritage, edited by Laurajane Smith and Natsuko Akagawa, 145-164. London: 
Routledge.

Smeets, Rieks and Harriet Deacon. 2017. "The Examination of Nomination Files Under the UNESCO Convention for the Safeguarding of the Intangible Heritage." In The Routledge Companion to Intangible Heritage, edited by Michelle Stefano and Peter Davis, 12-22. London: Routledge.

Smith, Laurajane. 2006. Uses of Heritage. London: Routledge.

Stovel, Herb. 2007. "Effective Use of Authenticity and Integrity as World Heritage Qualifying Conditions." City \& Time 2 (3): 21-36.

Tebbaa, Ouidad. 2010. “The Heritage of the Jemaa El Fna Square in Marrakech: Between The Material and The Immaterial." [Le patrimoine de la place Jemaa El Fna de Marrakech: entre le matériel et l'immatériel.] Quaderns de la Mediterrània 13: 51-58.

UNESCO 1972. "Convention Concerning the Protection of the World Cultural and Natural Heritage." Accessed 20 December 2018. https://whc.unesco.org/archive/ convention-en.pdf

UNESCO 1976. "Nairobi Recommendation Concerning the Safeguarding and Contemporary Role of Historic Areas." Accessed 20 December 2018. http:// portal.unesco.org/en/ev.php-URL_ID=13133\&URL_ DO=DO_TOPIC\&URL_SECTION=201.html

UNESCO 2003. "Convention for the Safeguarding of the Intangible Cultural Heritage.” Accessed 20 December 2018. http://portal.unesco.org/en/ev.php-URL_ $\mathrm{ID}=17716 \& \mathrm{URL}$ _DO $=\mathrm{DO} \_$TOPIC\&URL_SEC TION=201.html

UNESCO 2005. "Vienna Memorandum on World Heritage and Contemporary Architecture - Managing the Historic Urban Landscape.” Accessed 20 December 2018. http://whc.unesco.org/uploads/activities/documents/activity-47-2.pdf

UNESCO 2010. "Adoption of Retrospective Statements of Outstanding Universal Value." WHC-10/34.COM/8E. Add. Accessed 20 December 2018. http://whc.unesco. org/archive/2010/whc10-34com-8E.Add2e.pdf

UNESCO 2011. "Recommendation on the Historic Urban Landscape.” Accessed 20 December 2018. http://portal. unesco.org/en/ev.php-URL_ID $=48857 \% 26 \mathrm{URL}$ DO=DO_TOPIC\%26URL_SECTION=201.html

UNESCO 2017. "Operational Guidelines for the Implementation of the World Heritage Convention." Accessed 20 December 2018. http://whc.unesco.org/en/ guidelines/

UNESCO 2018. "Operational Directives for the
Implementation of the Convention for the Safeguarding of the Intangible Cultural Heritage." Accessed 20 December 2018. https://ich.unesco.org/en/directives

UNESCO. 2018. "World Heritage Centre: UNESCO Recommendation on the Historic Urban Landscape." Accessed December 20 2018. https://whc.unesco.org/ en/hul/

United Nations. 2015. “Transforming Our World: The 2030 Agenda for Sustainable Development." Accessed 20 December 2018. https://sustainabledevelopment. un.org/post2015/transformingourworld

United Nations. 2016. "New Urban Agenda: Quito Declaration on Sustainable Cities and Human Settlements for All.” Accessed 20 December 2018. http://habitat3. org/the-new-urban-agenda

Van Oers, Ron, 2010. "Managing Cities and the Historic Urban Landscape Initiative-An Introduction." In Managing Historic Cities: World Heritage Papers 37, edited by Ron van Oers and Sachiko Haraguchi, 7-17. Paris: UNESCO World Heritage Centre.

WHITRAP (World Heritage Institute of Training and Research for the Asia and the Pacific Region under the auspices of UNESCO). 2016. The HUL Guidebook: Managing Heritage in Dynamic and Constantly Changing Urban Environments. UNESCO: Paris. 